\title{
Deoxycytidylate Deaminase
}

National Cancer Institute

\section{Source}

National Cancer Institute. Deoxycytidylate Deaminase. NCI Thesaurus. Code C53621.

Deoxycytidylate deaminase (178 aa, $\sim 20 \mathrm{kDa}$ ) is encoded by the human DCTD gene. This protein plays a role in the conversion of deoxycytidine to deoxyuridine. 